\title{
Gambaran kadar kreatinin serum pada pasien penyakit ginjal kronik stadium 5 non dialisis
}

\author{
${ }^{1}$ Astrid A. Alfonso \\ ${ }^{2}$ Arthur E. Mongan \\ ${ }^{2}$ Maya F. Memah
}

\author{
${ }^{1}$ Kandidat Skripsi Fakultas Kedokteran Universitas Sam Ratulangi Manado \\ ${ }^{2}$ Bagian Patologi Klinik Fakultas Kedokteran Universitas Sam Ratulangi Manado \\ Email: astrid_alfonso12004@yahoo.co.id
}

\begin{abstract}
Chronic kidney disease is a pathophysiology process with various etiology, causing a progressive decline on kidney function, and in general ends with kidney failure (stage 5). For the last forty years, creatinine serum had been the most common and affordable detection serum to measure kidney performance. The amount of creatinine serum is increased on nondialysis chronic kidney disease patients. Approximately, 57\% of non-dialysis chronic kidney disease patients have 7-12 mg/dL creatinine level. Research objective: To understand the description of creatinine serum level on non-dialysis chronic kidney disease patients. Research method: Cross sectional descriptive, to obtain the data of creatinine serum on non-dialysis chronic kidney disease patients carried out on December 2015 - January 2016 at two hospitals, which are RSUP. Prof. Dr. R. D. Kandou Manado and Rumah Sakit Advent Manado. The research sample were the blood sample from 35 people suffering a stage five non dialysis chronic kidney disease, which determined by consecutive sampling from non-probability sampling model. Result: Based on the laboratory result, the 35 patients diagnosed with a stage five non dialysis chronic kidney disease are undergoing an increase on creatinine serum (100\%). Conclusion: Based on the research result, it can be concluded that the increase of creatinine level is occurred on stage five non dialysis chronic kidney disease patients.
\end{abstract}

Keywords: creatinine serum, stage five chronic kidney disease, non-dialysis.

\begin{abstract}
Abstrak: Penyakit ginjal kronik adalah suatu proses patofisiologi dengan etiologi yang beragam, mengakibatkan penurunan fungsi ginjal yang progresif, dan pada umumnya berakhir dengan gagal ginjal (stadium 5). Selama 40 tahun terakhir, kreatinin serum telah menjadi petanda serum paling umum dan murah untuk mengetahui fungsi ginjal. Kadar kreatinin serum meningkat pada pasien gagal ginjal non dialisis. Sekitar 57\% dari pasien gagal ginjal non dialisis memiliki kadar kreatinin 7-12 mg/dL. Tujuan Penelitian: untuk mengetahui gambaran kadar kreatinin serum pada pasien penyakit ginjal kronik stadium 5 non dialisis. Metode Penelitan: deskriptif cross sectional, untuk mendapatkan data tentang kadar kreatinin serum pada pasien penyakit ginjal kronik stadium 5 non dialisis yang dilakukan sejak Desember 2015-Januari 2016 di dua rumah sakit yaitu RSUP. Prof. Dr. R. D. Kandou Manado dan Rumah Sakit Advent Manado. Sampel penelitian adalah sampel darah dari 35 orang yang menderita penyakit ginjal kronik stadium 5 non dialisis ditentukan dengan cara non-probability sampling jenis consecutive sampling. Hasil: Berdasarkan hasil pemeriksaan laboratorium yang dilakukan, terdapat 35 pasien yang terdiagnosis penyakit ginjal kronik stadium 5 non dialisis mengalami peningkatan kadar kreatinin serum (100\%). Simpulan: Dari hasil penelitian dapat disimpulkan bahwa terjadi peningkatan kadar kreatinin serum pada pasien penyakit ginjal kronik stadium 5 non dialisis.
\end{abstract}

Kata kunci: kreatinin serum, penyakit ginjal kronik stadium 5, non dialysis 
Penyakit ginjal kronik (PGK) adalah suatu proses patofisiologi dengan etiologi yang beragam, mengakibatkan penurunan fungsi ginjal yang progresif, dan pada umumnya berakhir dengan gagal ginjal. ${ }^{1}$ Penyakit ginjal kronik telah menjadi suatu masalah kesehatan utama masyarakat dunia. ${ }^{2}$

Menurut United Stated Renal Data System di Amerika Serikat prevalensi PGK meningkat 20-25\% setiap tahun. Dari daftar 10 penyakit terbanyak di Irina C2 dan C4 RSUP Prof. Dr. R. D. Kandou Manado, PGK menempati peringkat pertama. Pasien PGK pada bulan Mei hingga September 2014 berjumlah 80 orang, pasien laki-laki sebanyak 51 orang dan pasien wanita sebanyak 29 orang. ${ }^{3}$

Pada stadium dini PGK, terjadi kehilangan daya cadang ginjal (renal reserve), pada keadaan laju filtrasi glomerulus (LFG) masih normal atau meningkat. Kemudian secara perlahan akan terjadi penurunan fungsi nefron yang progresif, yang ditandai dengan peningkatan kadar urea dan kreatinin serum. Pada LFG sebesar $60 \%$, pasien masih belum merasakan keluhan tapi sudah terjadi peningkatan kadar urea dan kreatinin serum. Pada LFG 30\%, mulai terjadi keluhan seperti nokturia, badan lemah, mual, nafsu makan berkurang, dan penurunan berat badan. Pada LFG $<30 \%$ pasien memperlihatkan gejala dan tanda uremia yang nyata, seperti anemia, peningkatan tekanan darah, mual dan sebagainya. Sedangkan pada LFG 15\% akan terjadi gejala dan komplikasi yang lebih serius antara lain dialisis atau transplantasi ginjal. Pada keadaan ini pasien dikatakan sampai pada stadium 5 atau disebut gagal ginjal. ${ }^{4}$ Kadar kreatinin serum meningkat pada pasien gagal ginjal non dialisis. Sekitar 57\% dari pasien gagal ginjal non dialisis memiliki kadar kreatinin $7-12 \mathrm{mg} / \mathrm{dL}^{5}$

Selama 40 tahun terakhir, kreatinin serum telah menjadi petanda serum paling umum dan murah untuk mengetahui fungsi ginjal. ${ }^{6}$ Pemeriksaan kreatinin serum juga sangat membantu kebijakan dalam melakukan terapi pada pasien gangguan fungsi ginjal. Tinggi rendahnya kadar kreatinin dalam darah digunakan sebagai indikator penting dalam menentukan apakah seorang dengan gangguan fungsi ginjal memerlukan tindakan hemodialisis atau tidak. $^{7}$

Kreatinin merupakan hasil metabolisme dari kreatin dan fosfokreatin. Kreatinin memiliki berat molekul 113-Da (Dalton). Kreatinin difiltrasi di glomerulus dan direabsorpsi di tubular. Kreatinin plasma disintesis di otot skelet sehingga kadarnya bergantung pada massa otot dan berat badan. ${ }^{8}$ Nilai normal kadar kreatinin serum pada pria adalah 0,7-1,3 $\mathrm{mg} / \mathrm{dL}$ sedangkan pada wanita $0,6-1,1 \mathrm{mg} / \mathrm{dL}$. $^{9}$

Proses awal biosintesis kreatin berlangsung di ginjal yang melibatkan asam amino arginin dan glisin. Menurut salah satu penelitian in vitro, kreatin diubah menjadi kreatinin dalam jumlah 1,1\% per hari. Pada pembentukan kreatinin tidak ada mekanisme reuptake oleh tubuh, sehingga sebagian besar kreatinin diekskresi lewat ginjal. $^{10}$

Jika terjadi disfungsi renal maka kemampuan filtrasi kreatinin akan berkurang dan kreatinin serum akan meningkat. Peningkatan kadar kreatinin serum dua kali lipat mengindikasikan adanya penurunan fungsi ginjal sebesar $50 \%$, demikian juga peningkatan kadar kreatinin serum tiga kali lipat merefleksikan penurunan fungsi ginjal sebesar $75 \%{ }^{11}$

Ada beberapa penyebab peningkatan kadar kreatinin dalam darah, yaitu dehidrasi, kelelahan yang berlebihan, penggunaan obat yang bersifat toksik pada ginjal, disfungsi ginjal disertai infeksi, hipertensi yang tidak terkontrol, dan penyakit ginjal. ${ }^{12}$

Tujuan dari penelitian ini adalah untuk mengetahui gambaran kadar kreatinin serum pada pasien PGK stadium 5 non dialisis.

\section{METODE PENELITIAN}

Penelitian ini merupakan studi deskriptif cross sectional. Penelitian dilaksanakan di dua rumah sakit yaitu 
Poliklinik Nefrologi-Hipertensi dan rawat inap bagian Penyakit Dalam RSUP. Prof. Dr. R. D. Kandou Manado dan Rumah Sakit Advent Manado selama bulan Desember 2015 sampai Januari 2016. Sampel penelitian adalah sampel darah dari semua pasien PGK stadium 5 non dialisis dalam kurun waktu dan kriteria yang telah ditentukan dengan cara non-probability sampling jenis consecutive sampling.

\section{HASIL PENELITIAN}

Tabel 1. Distribusi pasien penyakit ginjal kronik stadium 5 non dialisis menurut usia

\begin{tabular}{ccc}
\hline Usia & Jumlah & $\%$ \\
\hline 26-35 Tahun & 1 & $2,86 \%$ \\
36-45 Tahun & 2 & $5,71 \%$ \\
46-55 Tahun & 8 & $22,86 \%$ \\
56-65 Tahun & 7 & $20 \%$ \\
66-75 Tahun & 13 & $37,14 \%$ \\
>75 Tahun & 4 & $11,43 \%$ \\
\hline Jumlah & $\mathbf{3 5}$ & $\mathbf{1 0 0 \%}$ \\
\hline
\end{tabular}

Tabel 2. Distribusi pasien penyakit ginjal kronik stadium 5 non dialisis menurut jenis kelamin

\begin{tabular}{ccc}
\hline $\begin{array}{c}\text { Jenis } \\
\text { kelamin }\end{array}$ & Jumlah & $\%$ \\
\hline Laki-laki & 21 & $60 \%$ \\
Perempuan & 14 & $40 \%$ \\
\hline Total & $\mathbf{3 5}$ & $\mathbf{1 0 0 \%}$ \\
\hline
\end{tabular}

Tabel 3. Distribusi pasien penyakit ginjal kronik stadium 5 non dialisis menurut riwayat penyakit dahulu

\begin{tabular}{ccc}
\hline Riwayat & Jumlah & $\%$ \\
penyakit dahulu & & $83 \%$ \\
Hipertensi & 29 & $23 \%$ \\
Diabetes melitus & 8 & $43 \%$ \\
Asam urat & 15 & \\
\hline
\end{tabular}

Tabel 4. Distribusi pasien penyakit ginjal kronik stadium 5 non dialisis menurut hasil pemeriksaan kreatinin

\begin{tabular}{cccc}
\hline $\begin{array}{c}\text { Jenis } \\
\text { kelamin }\end{array}$ & Jumlah & $\%$ & $\begin{array}{c}\text { Rerata kadar } \\
\text { kreatinin }\end{array}$ \\
\hline Laki-laki & 21 & $60 \%$ & $7,39 \mathrm{mg} / \mathrm{dL}$ \\
Perempuan & 14 & $40 \%$ & $6,39 \mathrm{mg} / \mathrm{dL}$ \\
\hline
\end{tabular}

Tabel 5. Distribusi hasil pemeriksaan kreatinin pasien PGK stadium 5 non dialisis berdasarkan jenis pelayanan medis

\begin{tabular}{cccc}
\hline $\begin{array}{c}\text { Pelayanan } \\
\text { medis }\end{array}$ & Jumlah & $\%$ & $\begin{array}{c}\text { Rerata } \\
\text { kadar } \\
\text { kreatinin }\end{array}$ \\
\hline Rawat jalan & 17 & $48,6 \%$ & $\begin{array}{c}7,5 \\
\mathrm{mg} / \mathrm{dL} \\
6,6 \\
\mathrm{mg} / \mathrm{dL}\end{array}$ \\
\hline
\end{tabular}

\section{BAHASAN}

Berdasarkan data yang diperoleh pada Tabel 1, terdapat 1 orang (2,86\%) pada kelompok usia 26-35 tahun, 2 orang (5,71\%) pada kelompok usia 36-45 tahun, 8 orang pada kelompok usia 46-55 tahun (22,86\%), 7 orang pada kelompok 56-65 tahun (20\%), 13 orang pada kelompok usia 66-75 tahun $(37,14 \%)$, dan 4 orang di atas 75 tahun (11,43\%). Berdasarkan pembagian ini tentu dapat dilihat bahwa kelompok usia 66-75 tahun merupakan kelompok usia terbanyak yang menderita PGK stadium 5 non dialisis. Hasil ini berbeda dengan data dari United States Renal Data System Annual Data Report (2013) yang menunjukkan bahwa kelompok usia 45-64 tahun (45\%) merupakan kelompok usia terbanyak yang menderita PGK stadium 5 non dialisis. ${ }^{13}$ Sedangkan data dari National Health Service (NHS) di Inggris menunjukkan bahwa prevalensi pasien PGK stadium 5 pada kelompok usia 18-25 tahun adalah kurang dari $1 \%$ dan meningkat pada kelompok usia 85 tahun $(44,75 \%) .{ }^{14}$ Prevalensi PGK meningkat seiring dengan bertambahnya usia. ${ }^{15}$

Berdasarkan data yang diperoleh pada Tabel 2, terdapat 21 orang laki-laki (60\%) dan 14 orang perempuan (40\%). Hasil ini sama dengan data dari United States Renal Data System Annual Data Report (2013) yang menunjukkan bahwa pasien laki-laki (56,8\%) lebih banyak dari perempuan $(43,2 \%) .{ }^{13}$ Namun berbeda dengan data dari National Health Service di Inggris yang menunjukkan bahwa pasien perempuan $(10,6 \%)$ lebih banyak dari laki- 
laki $(5,8 \%) .{ }^{14}$ Hasil tersebut juga sama seperti penelitian yang dilakukan oleh Pura dkk di RS Hasan Sadikin Bandung menunjukkan perbandingan antara jumlah laki-laki dan perempuan adalah $2: 1^{16}$ Namun berbeda dengan penelitian yang dilakukan oleh Tjekyan di RSUP Dr. Mohammad Hoesin Palembang yang menunjukkan bahwa pasien perempuan (56,3\%) lebih banyak dari laki-laki $(43,7 \%) .{ }^{17} \quad$ Perbandingan tersebut menunjukkan bahwa jenis kelamin tidak berpengaruh pada prevalensi PGK.

Berdasarkan Tabel 3 terlihat dari 35 pasien PGK stadium 5 non dialisis, terdapat 29 orang dengan riwayat hipertensi (83\%), 8 orang dengan riwayat diabetes melitus (23\%), dan 15 orang dengan riwayat asam urat (43\%). Berdasarkan pembagian ini tentu dapat dilihat bahwa hipertensi merupakan riwayat penyakit dahulu yang terbanyak pada pasien PGK stadium 5 non dialisis. Hasil ini berbeda dengan data dari United States Renal Data System Annual Data Report (2013) yang menunjukkan bahwa diabetes (37,9\%) merupakan penyebab terbanyak PGK stadium $5 .^{13}$ Namun hasil ini sesuai dengan data dari Indonesian Renal Registry yang menunjukkan bahwa hipertensi (34\%) merupakan penyebab terbanyak PGK stadium $5{ }^{18}$ Hipertensi merupakan salah satu penyebab PGK stadium 5 melalui suatu proses yang mengakibatkan hilangnya sejumlah besar nefron fungsional yang progresif dan irreversible. Peningkatan tekanan dan regangan yang kronik pada arteriol dan glomerulus dapat menyebabkan sklerosis pada pembuluh darah glomerulus. Penurunan jumlah nefron akan menyebabkan proses adaptif, yaitu meningkatnya aliran darah, peningkatan LFG dan peningkatan keluaran urin di dalam nefron yang masih bertahan. Proses ini melibatkan hipertrofi dan vasodilatasi nefron serta perubahan fungsional yang menurunkan tahanan vaskular dan reabsorbsi tubulus di dalam nefron yang masih bertahan. Perubahan fungsi ginjal dalam waktu yang lama dapat mengakibatkan kerusakan lebih lanjut pada nefron yang ada. Hal ini menyebabkan penurunan fungsi ginjal lebih lanjut yang dapat berakhir sebagai PGK stadium 5 atau gagal ginjal. ${ }^{19}$

Pada Tabel 4 dapat dilihat bahwa 35 pasien PGK stadium 5 non dialisis mengalami peningkatan kadar kreatinin serum (100\%) dengan rerata kadar kreatinin pada laki-laki sebesar 7,39 mg/dL dan perempuan sebesar 6,39 mg/dL. Hasil tersebut menunjukkan bahwa laki-laki memiliki kadar kreatinin yang lebih tinggi daripada perempuan. Rata-rata kadar kreatinin semua pasien pada penelitian ini adalah sebesar 6,9 mg/dL, dengan kadar kreatinin terendah $1,67 \mathrm{mg} / \mathrm{dL}$ dan kadar kreatinin tertinggi $17,7 \mathrm{mg} / \mathrm{dL}$. Hasil ini tidak jauh berbeda dengan penelitian yang dilakukan di RSUD Dr. Moewardi Surakarta yang menunjukkan bahwa terdapat 31 pasien $(93,9 \%)$ PGK yang memiliki kadar kreatinin tinggi. ${ }^{20}$ Sekitar $57 \%$ dari pasien gagal ginjal non dialisis memiliki kadar kreatinin 7-12 mg/dL. ${ }^{5}$ Kreatinin disintesis di otot skelet sehingga kadarnya bergantung pada massa otot. Laki-laki memiliki massa otot yang lebih tinggi daripada perempuan sehingga kadar kreatinin pada laki-laki lebih tinggi daripada perempuan. ${ }^{8}$ Hasil pemeriksaan laboratorium (Tabel 4) tersebut juga sesuai dengan teori yang mengatakan bahwa jika terjadi disfungsi renal maka kemampuan filtrasi kreatinin akan berkurang dan kreatinin serum akan meningkat. Peningkatan kadar kreatinin serum dua kali lipat mengindikasikan adanya penurunan fungsi ginjal sebesar 50\%, demikian juga peningkatan kadar kreatinin serum tiga kali lipat merefleksikan penurunan fungsi ginjal sebesar $75 \% .^{11}$ Salah satu fungsi ginjal yang terpenting adalah ekskresi produk sisa metabolik seperti kreatinin. ${ }^{21}$ Fungsi tersebut sangat terganggu pada pasien gagal ginjal non dialisis akibatnya kadar kreatinin serum meningkat. ${ }^{5}$ Oleh sebab itu kadar kreatinin serum digunakan sebagai indikator penting untuk mengetahui fungsi ginjal.

Pada Tabel 5 dapat dilihat dari 35 pasien PGK stadium 5 non dialisis, terdapat 
17 pasien rawat jalan (48,6\%) dan 18 pasien rawat inap (51,4\%). Rerata kadar kreatinin pasien rawat jalan adalah 7,5 $\mathrm{mg} / \mathrm{dL}$ dan 6,6 $\mathrm{mg} / \mathrm{dL}$ pada pasien rawat inap. Rerata kadar kreatinin pasien rawat jalan sedikit lebih meningkat dibanding rerata kadar kreatinin pasien rawat inap. Hal ini mungkin terjadi karena pasien rawat inap mendapat pelayanan medis yang lebih intensif atau intervensi sebelumnya misalnya diet yang baik.

LImitasi penelitian ini adalah tidak melihat faktor-faktor yang mempengaruhi sebab dan akibat, keterbatasan waktu penelitian yang membatasi jumlah subjek yang terkumpul, dan persiapan pengukuran pasien mungkin tidak sesuai dengan prosedur.

\section{SIMPULAN}

Berdasarkan hasil penelitian yang dilakukan di Poliklinik NefrologiHipertensi dan rawat inap bagian Penyakit Dalam RSUP. Prof. Dr. R. D. Kandou Manado serta Rumah Sakit Advent Manado, penulis menarik kesimpulan bahwa terjadi peningkatan kadar kreatinin serum pada pasien penyakit ginjal kronik stadium 5 non dialisis.

\section{DAFTAR PUSTAKA}

1. Suwitra K. Penyakit ginjal kronik. Dalam Sudoyo Aru W, Setiyohadi Bambang, Alwi Idrus. Editors: Buku Ajar Ilmu Penyakit Dalam. Jilid II, Edisi V. Jakarta. Interna publishing;2009.p.1035.

2. Zhang Q, Rothenbacher D. Prevalence of chronic kidney disease in populationbased studies: systematic review. 11 April 2008. Available from: www.biomedcentral.com/14712458/8/117

3. Sumigar G, Rompas S, Pondaag L. Hubungan dukungan keluarga dengan kepatuhan diet pada pasien gagal ginjal kronik di irina C2 dan C4 RSUP Prof. Dr. R. D. Kandou Manado. 2015;3:2.

4. Suwitra K. PGK. Dalam Sudoyo Aru W, Setiyohadi Bambang, Alwi Idrus. Editors: Buku Ajar Ilmu Penyakit
Dalam. Jilid II, Edisi V. Jakarta. Interna publishing;2009.p.1036.

5. Amin N, Mahmood R, Asad M, Zafar M, Raja A. Evaluating Urea and Creatinine Levels in Chronic Renal Failure Pre and Post Dialysis : A Prospective Study. 2014;Vol.2:No.2.1.

6. Widyastiti N. Perbedaan nilai klirens Cockroft-Gault berdasar hasil pemeriksaan kreatinin metode Jaffe uncompensated, rate-blanked compensated dengan enzimatik. [Tesis]. Semarang : FK UNDIP;2005.

7. National Institute for Helath Research. Point-of-care creatinine testing for the detection and monitoing of chronic kidney disease. Oxford Journal. 2014.1-3.

8. Banerjee A. Renal physiology. In : Clinical physiology an examination primer. USA : Cambridge University Press;2005.p.61.

9. David C. Dugdale. Creatinine blood test. 8 April 2013. Available from : https://www.nlm.nih.gov/medlineplus /ency/article/003475.htm

10.Wulandari W. Jalur metabolisme kreatinin. 2015. Available from : http://www.academia.edu/9986413/45 125261-jalur-metabolisme-kreatinin

11.Anonym. Serum Creatinine. 2000 : 1-3. http://www.rnceus.com/renal/renalcre at.html

12.Kidney failure. High creatinine level. 12 September 2013. Available from: http://www.kidneyfailureweb.com/cre atinine/251.html

13.Nicola $L$, Minutolo $R$, Chiodini $P$, Borrelli S, Zoccali C, Postorino M, dkk. The effect of increasing age on the prognosis of non-dialysis patients with chronic kidney disease receiving stable nephrology care. National Kidney Foundation Journal. 2012;82:482-8.

14.East Midlands Public Health Observatory. Kidney disease : key facts and figures. NHS Kidney Care.2010.p.13.

15.Prakash, S, O’Hare AM. Interaction of Aging and CKD. Semin Nephrol. 2009; 29(5):497-503.

16.Pura L, Supriyadi R, Nugraha GI, Bandiara R, Soalaeman $\mathbf{R}$. Hubungan filtrasi glomerulus dengan 
status nutrisi pada pasien PGK predialisis. Kidney Int. 2006;70:41722.

17.Tjekyan R. Prevalensi dan Faktor Risiko PGK di RSUP Dr. Mohammad Hoesin Palembang Tahun 2012. Jurnal Fakultas Kedokteran Universitas Sriwijaya. 2014:277.

18. Perkumpulan nefrologi Indonesia. Report of Indonesia Renal Registry. Edisi 4. 2011.p.13.

19.Nurjanah A. Hubungan antara lama hipertensi dengan angka kejadian gagal ginjal terminal di RSUD Dr. Moewardi Surakarta. Naskah publikasi Universitas Muhammadiyah Surakarta.2012.p.7.

20.Martini, Endang W, Mutalazimah. Hubungan tingkat asupan protein dengan kadar ureum dan kreatinin darah pada pasien gagal ginjal kronik di RSUD Dr. Moewardi Surakarta. Jurnal kesehatan. 2010;3:23.

21.Guyton AC, Hall JE. Pembentukan urin oleh ginjal: 1. Filtrasi glomerulus, aliran darah ginjal, dan pengaturannya. Dalam: Buku ajar fisiologi kedokteran. Edisi 9. Jakarta: EGC; 1997.p.397-8. 